\title{
Comparison of the sowing, harvesting and antioxidant properties of seeds and seedlings of a giant field moth (Agrostis gigantea Roth) after air drying and thermal dehydration
}

\author{
(C) Valery N. Zelenkov, ${ }^{1,2}$ Vyacheslav V. Latushkin, ${ }^{3}$ \\ Anatoly A. Lapin, ${ }^{4}{ }^{+}$and Vladimir M. Kosolapov ${ }^{5}$ \\ ${ }^{1}$ All-Russian Scientific Research Institute of Medicinal and Aromatic Plants. \\ Greene St., 7. Moscow, 117216.Russia.E-mail:zelenkov-raen@mail.ru \\ ${ }^{2}$ All-Russian Scientific Research Institute of Vegetable Growing - the branch of FSBSI "Federal \\ Scientific Vegetable Center". 500 Vereya village, Ramenskoe district, 140153. Moscow Region. Russia. \\ ${ }^{3}$ INPO “Institute for Development Strategies" Stoleshnikov Lane, 11. Moscow, 107031. Russia. \\ ${ }^{4}$ Department of Water Bioreservices and Aquaculture. Kazan Energy University. Krasnoselskaya St., 51. \\ Kazan, 420066. Republic of Tatarstan. Russia. Phone: +7 (843) 519-42-67.E-mail: lapinanatol@mail.ru \\ ${ }^{5}$ Federal Scientific Center for Feed Production and Agroecology Williams (Federal Research Center "VIK \\ named after V.R. Williams") Science campus, building 1. Lobnya. Moscow Region, 141055. Russia.
}

\begin{abstract}
*Supervising author; ${ }^{+}$Corresponding author
Keywords: antioxidant activity, total antioxidant activity, coulometric analysis method, water, giant polevole, thermohydration, seed germination, germination.
\end{abstract}

Abstract
The study of the biological characteristics of feed crops and the use of modern methods in the study of the processes of their selection is relevant for the intensification of feed production. The article presents the results of a biochemical study of the giant VIK-2 (Agrostis gigantea Roth) field birch seed, their sowing and yield properties after thermal dehydration (drying of air-dried samples at $105{ }^{\circ} \mathrm{C}$ to constant weight), as well as their total antioxidant activity during germination in the dark. The total antioxidant activity of seeds and seedlings was studied using coulometric analysis and determined using electrogenerated bromine, the samples were analyzed on a certified couponometer Expert-006 (LLC Econix-Expert, Russia) using a certified method. The work shows that, compared with air drying after thermohydration, there is a decrease in the viability and yield properties of seeds. Seed germination decreased by $5.5 \%$, the height of plants at the end of the germination period (on the 14th day after sowing) by $9.4 \%$, the mass of 100 sprouts - by $21.3 \%$, the yield of green mass (microgreen) also by $21.3 \%$. The antioxidant activity of seeds after thermal dehydration also decreased by $21.4 \%$. For the first time, data were obtained on the viability, formation of microgreen biomass and a change in the total antioxidant activity of the seeds of the VIK-2 giant cultivar after thermal dehydration (drying the initial seeds) in the test at $105^{\circ} \mathrm{C}$ to constant weight. It was shown that thermal dehydration of seeds at $105^{\circ} \mathrm{C}$ significantly affects the viability of seeds and seedlings of a bent field, which is associated with the characteristics of metabolism, forms and state of water activity in cells and tissues of plants.

\section{References}

[1] Handbook of feed production. 4th edition. revised and supplemented. Edited by V.M. Kosolapova, I.A. Trofimova. Moscow: Publishing house of the Russian Agricultural Academy. 2011. 700p. (russian)

[2] V.M. Kosolapov, I.A. Trofimov, L.S. Trofimova. Fodder production in agriculture, ecology and environmental management (theory and practice). Moscow: Publishing house of the Russian Agricultural Academy. 2014. 137p. (russian)

[3] A.A. Lapin, Yu.V. Chesnokov, V.M. Kosolapov. Plant genetic resources and acceleration of the selection process. Moscow: Publishing house LLC "Ugreshskaya typography". 2016. 172p. (russian)

[4] V.N. Zelenkov, A.V. Polyakov. Features of water removal from garlic teeth of different varieties under infrared irradiation at $105^{\circ} \mathrm{C}$. New and unconventional plants and prospects for their use: a collection of scientific papers based on XIII International Symposium. Moscow: Publishing House of RUDN. 2019. 184p. P.164-166. (russian)

[5] V.N. Zelenkov, M.N. Pavlov, Z.I. Usanova. Dynamics of water removal from Jerusalem artichoke leaves and tubers of Interest under infrared irradiation at $105^{\circ} \mathrm{C} / / \mathrm{New}$ and unconventional plants and 

prospects for their use: a collection of scientific papers based on the materials of the XIII International Symposium. Moscow: Publishing House of RUDN. 2019. 184p. P.173-175. (russian)

[6] V.N. Zelenkov, V.V. Latushkin, A.A. Lapin, M.V. Markov, V.V. Karpachev, P.A. Vernik, S.V. Gavrilov, V.V. Novikov. Impact of pulsed irradiation on germination and antioxidant content during germination of Abyssinian nougat seeds in the closed synergotron system ISR-1.1. "The role of physiology and biochemistry in the introduction and selection of agricultural plants": Proceedings of the Y International Scientific and Methodological Conference (Moscow, April 15-19, 2019). Moscow: Publishing House of RUDN. 2019. Vol.1. P.314-317. DOI: 10.22363 / 09358-2019-314-317

[7] V.N. Zelenkov, V.V. Latushkin, M.I. Ivanova, A.A. Lapin, O.A. Razin, S.V. Gavrilov, P.A. Vernik. The effect of lighting on the germination of Chinese cabbage and broccoli and the antioxidant activity of microgreens in the closed synergotron system ISR 1.01. Vegetables of Russia. 2019. No.6. P.146-150. https: // doi.org/10.18619/2072-9146-2019-6-146-150

[8] V.N. Zelenkov, V.V. Latushkin, M.I. Ivanova, A.A. Lapin, S.V. Gavrilov, P.A. Vernik. The effect of lighting on the growth and antioxidant activity of radish seedlings during cultivation under controlled conditions of the synergotron on ISR 1.01. Actual biotechnology. 2019. No.3(30). P.66-69. (russian)

[9] V.N. Zelenkov, A.A. Lapin, V.V. Karpachev, V.V. Latushkin, M.I. Ivanova, S.V. Gavrilov, P.A. Vernik, V.P. Baryshok. Antioxidant activity of Abyssinian nougat seedlings under different modes of pulsed lighting and the use of mineral nutrient solutions. Actual biotechnology. 2019. No.3(30). P.103-105. (russian)

[10] V.N. Zelenkov, A.A. Kosobryukhov, A.A. Lapin, M.I. Ivanova, V.V. Latushkin. Productivity and antioxidant activity of mustard salad when irradiated with red and blue LEDs in a closed synergotron system ISR-1.1. Proceedings of the Federal Center for Science and Technology. 2019. No.1. P.83-86. (russian)

[11] V.N. Zelenkov, V.N. Petrichenko, A.A. Lapin, and V.P. Baryshok. Biotechnological aspects of the use of complex preparation 1-ethoxysilatrane with crezacin in crop production. Butlerov Communications. 2019. Vol.60. No.11. P.69-74. DOI: $10.37952 / R O I-j b c-02 / 19-60-11-69$

[12] A.A. Lapin, L.G. Grechukhina, and V.N. Zelenkov. Feed additive of amaranth for fish. Part 1. Antioxidant properties of amaranth seeds. Butlerov Communications. 2012. Vol.32. No.13. P.110-117. ROI-jbc-02/12-32-13-110

[13] GOST 12038-84. Seeds of crops. Germination Methods. Moscow: Publishing house of the STANDARTINFORM. 2011. 31p. (russian)

[14] MX-50 humidity analyzer, zA VUser handbook. Version 2.20 / February, 2003. A\&DCompany, Limited/External Trade Department. 31p. (russian)

[15] V.N. Zelenkov, A.A. Lapin. Total antioxidant activity. Measurement technique on a coulometric analyzer. MVI-01-00669068. Vereya, Moscow Region: All-Russian Research Institute of Vegetable Production. 2013. 19p. (russian)

[16] TU 9369-141-04868244-07. Rutin is the standard. Technical conditions. (russian)

[17] State Pharmacopoeia of the USSR. Iss.2. General methods of analysis. Medicinal plant material. Ministry of Health of the USSR. 11th ed. Moscow: Medicine. 1989. 398p. (russian)

[18] D. Jezepov. Fashion in statistics. [Electronic resource]- URL: http://statanaliz.info/metody/opisaniedannyx/56-moda (date of the application 10.07. 2019). (russian) 